\title{
JUSTIÇA E CONTRADIÇÃO. DISSÍDIO E RECONCILIAÇÃO(?) NA INTERPRETAÇÃO DO SOFISTA ANTIFONTE NO SÉCULO XX.
}

\section{JUSTICE AND CONTRADICTION. DISSENSION AND RECONCILIATION(?) IN $20^{\text {TH }}$ CENTURY INTERPRETATION OF ANTIPHON THE SOPHIST.}

\author{
Nuno Manuel Morgadinho dos Santos Coelho*
}

\begin{abstract}
Resumo: Este artigo examina as diferentes interpretações oferecidas por especialistas no século XX acerca da estrutura antilógica dos textos de Antifonte, intelectual Ateniense do Séc. V. a.C. autor do mais extenso conjunto de textos de que nos chegou da Sofística, entre os quais discursos forenses e fragmentos filosóficos que exercitam a antilogia como o poder de fazes dois discursos opostos sobre qualquer assuntos (na tradição de Protágoras) e problematizam fortemente o clássico binômico justiça natural e justiça convencional. As interpretações contemporâneas de Bignone, Untersteiner, Caizzi, Cassin e Gagarin enfatizam o caráter antilógico dos textos, mas são comuns em tentar encontrar, neles ou a partir deles, alguma forma de superação do dissídio e da contradição que os caracteriza. O presente estudo sugere que, ao fazê-lo, os especialistas estudados deixam de perceber aquele que talvez seja o traço central do pensamento de Antifonte, autor que estaria empenhado precisamente em mostrar o caráter insuperável do dissídio e da contradição que marcam a experiência humana do sentir, do pensar e do falar.
\end{abstract}

Palavras-chave: Antifonte; Antilogia; Sofística; Dissídio; Contradição.

\begin{abstract}
This article examines the different interpretations offered by contemporary experts on the antilogical structure of the texts of Antiphon, Ancient Athenian intellectual author of the most extensive set of texts that came to us from Sophistry including forensic discourses and fragments philosophical philosophers, which exercise Antilogiae as the power to make two opposing discourses on any subject (in the tradition of Protagoras) and strongly problematize the classical binomial natural justice and conventional justice. The interpretations of Bignone, Untersteiner, Caizzi, Cassin, and Gagarin emphasize the antilogical character of texts, but they are common in trying to find, in or from them, some way of overcoming the dissidence and the contradiction that characterizes them. The present study suggests that, in doing so, the specialists studied fail to perceive what is perhaps the central feature of Antiphon's thought, an author who would be striving precisely to show the insuperable character of dissidence and contradiction that mark the human experience in feeling, thinking and speaking.

Keywords: Antiphon; Antilogiae; Sophistry; Dissidence; Contradiction.
\end{abstract}

\footnotetext{
* Professor da Faculdade de Direito de Ribeirão Preto da USP e da UNAERP. Mestre e Doutor em Filosofia do Direito pela UFMG. Livre-Docente em Teoria do Direito pela USP. Pós-Doutor em Filosofia Antiga pela UFMG. Pós-Doutor em Filosofia do Direito pela Universidade de Munique. Contato: nunocoelho@usp.br.
} 


\section{INTRODUÇÃO}

Antifonte foi um dos poucos sofistas cidadãos de Atenas. Sua vida e sua obra são repletas de controvérsias. Os dados biográficos dão-nos conta de Antifonte atuando como logógrafo, por exemplo. Ele teria, a rigor, sido o primeiro a escrever discursos para que outros os lessem, em seus processos judiciais - com que teria sido o precursor do advogado. Também temos notícia de que foi professor de retórica, escritor de tratados sobre os diferentes assuntos objeto de discussão no século V. a.C., em que viveu (entre os títulos de seus tratados, estão Sobre a Verdade, Sobre a Concórdia, e Sobre a Revolução), poeta, escritor de tragédias, intérprete de sonhos e até logoterapeuta.

Sua vida e sua obra são tão surpreendentemente contraditórias, que a tradição levantou (e ainda sustenta) a possibilidade de serem dois ou mais os Antifontes a que se atribuem lances biográficos aparentemente irreconciliáveis, tais como a participação no golpe oligárquico dos 400 (que o levaria à morte, condenado pela democracia restaurada) - típica de um conservador - e a postulação teórica da igualdade entre todos os seres humanos, presente no fragmento 44 de Sobre a Verdade francamente revolucionária e extremamente original para aquele tempo.

Antifonte é fonte importantíssima para o estudo da Sofística. Em primeiro lugar, em razão de os seus discursos forenses e as suas Tetralogias constituírem o mais extenso corpo de textos que nos chegou de um sofista. Além disso, pelo fato de seus textos serem exemplares no exercício da Antilogia, o poder de fazer discursos opostos acerca de qualquer ponto.

Sobre este último aspecto versa o presente artigo, que revisita os mais importantes comentários dedicados à obra de Antifonte dos últimos cem anos, para investigar a leitura que fazem dos textos antifonteanos no que respeita à extensão do reconhecimento de sua estrutura antilógica.

Em que medida - de acordo com os autores rememorados - os textos de Antifonte são expressivos deste traço agonístico da cultura ática clássica, marcadamente retórica e dialética, veiculando e exercitando o poder de dizer os contrários?

A investigação em causa é relevante na medida em que permitirá ajudar a pensar o lugar de Antifonte na história do pensamento sobre a justiça.

A revisão de seu lugar na história da filosofia da justiça e do direito pode decorrer da consideração de que os seus muitas vezes citados fragmentos acerca da R. Fac. Dir. UFG, v. 42, n. 3, p.85-113, set./dez. 2018 
Justiça e contradição. Dissídio e reconciliação(?) na interpretação do sofista Antifonte no século XX

justiça e da igualdade universal entre todos os homens, não representam uma teoria que tenha defendido, mas tão somente um logos lançado em um jogo de logoi contrapostos, com o intuito de exercitar o poder de dizer discursos contrários.

Esta conclusão não diminui sua importância, mas decerto nos faz repensar seu lugar no quadro político e intelectual da Atenas do século V a. C.

Ele não representa, naquele momento, uma voz que se destaca pela defesa da igualdade, mas sim pela capacidade retórica de sustentar os pontos de vistas mais difíceis, ensinando seus alunos a fazê-lo.

Modifica-se seu lugar na história do pensamento sobre a justiça - na medida em que não pode ser tido como pioneiro defensor da igualdade universal (transpolítica) humana, já que o igualitarismo não seria por ele realmente defendido, embora o tenha audaciosamente expressado, a fim de demonstrar sua terrível capacidade de fazer discursos contrários à opinião corrente (paradóxicos).

Modifica-se, também, sua visão no quadro do século V. a.C., em que ele passa a ser visto como um filósofo com algo a dizer em termos tanto ontológicos quanto gnosiológicos e práticos (éticos, jurídicos e políticos) - se se admite que ele retire consequências, válidas para estas diferentes instâncias - radicalizando a perspectiva da Antilógica (de acordo com a qual sobre tudo se podem fazer discursos contrários).

Com qual radicalidade Antifonte mobilizou este princípio? Terá ele escrito seus tratados e discursos para demonstrar que não há - no plano ontológico, gnosiológico ou prático - instância de superação da divergência antilógica?

O objeto deste artigo analisa a interpretação oferecida pelos mais importantes intérpretes do Antifonte do último século, examinando a compreensão que tiveram desta pergunta - e ajudando-nos, assim, a construir a nossa própria resposta.

\section{A SOFÍSTICA NO QUADRO DA FILOSOFIA COMO ATITUDE ESPIRITUAL}

A filosofia, assumida por Husserl como atitude espiritual, forjada pelos gregos na gênese da civilização ocidental - de que a Sofística é momento singular caracteriza-se por uma visão de mundo marcada pela crítica invencível a que todo saber passa a expor-se:

o mais essencial da atitude teorética do homem filosófico é a peculiar universalidade da postura crítica, a qual está decidida a não aceitar sem 
questão qualquer opinião pré-dada, qualquer tradição, de modo a que possa perguntar logo de seguida, a respeito do todo do universo pré-dado segundo a tradição, pelo que é em si verdadeiro, por uma idealidade. (HUSSERL, 2006A, p. 115-120).

se a ideia geral da verdade em si se torna a norma universal de todas as verdades relativas que surgem na vida humana, das verdades de situação efectivas ou supostas, então isto também diz respeito a todas as normas tradicionais, às normas do Direito, da beleza, da utilidade, dos valores pessoais dominantes, dos valores pessoais do carácter, etc. (HUSSERL, 2006A, p. 120).

Jan Patočka, filósofo que se insere de modo original na mesma tradição fenomenológica, descreve a passagem do mito para a filosofia como um abalo, que traz a problematicidade do estar-no-mundo como traço permanente da nova forma de vida:

O mundo anterior à problematicidade é também o mundo do sentido dado, modesto porém seguro. O mundo está dotado de sentido, isto é, é compreensível, em virtude do fato de que há potências, de que há uma esfera do demoníaco, dos deuses situado acima do homem e que o governam e decidem por ele. O homem não está no centro do mundo, não é dele que se trata. Só recebe seu posto e com ele se contenta. (...) Podemos fazer mais próximo esse 'mundo natural', situado em algum lugar antes do início da nossa história, baseando-nos nas experiências e informações que possuímos dos povos ditos naturais. (...) O sobrenatural está sempre neles presente por oposição a - e como contrapartida evidente de - o humano (contra 'à direita' por oposição 'à esquerda', 'encima' por oposição a 'embaixo', o dia por oposição à noite e o dia de trabalho por oposição ao dia festivo). Neste mundo o homem pode encontrar espíritos, demônios e outros seres misteriosos, mas o mistério da manifestação enquanto tal não se apresenta, não pode iluminar-se para ele. $\mathrm{O}$ projeto fundamental das possibilidades de semelhante estar-no-mundo natural é existir nesse sentido não problemático. Este traço da vida natural sempre surpreendeu: os povos naturais aceitam ali onde estamos inseguros, parecem conhecer as respostas antes que se coloquem as perguntas. Como se o fato de que sua vida seja algo compreensível e que valha a pena ser vivida fosse algo óbvio. (PATOČKA, 1988, p. 30).

Enfatiza-se o desconforto ínsito à atitude filosófica, em que a provisoriedade, a não-definitividade de toda verdade tem impacto sobre todas as dimensões da vida humana. A problematicidade torna-se condição própria do humano, na nova atitude. Mantém-se sempre aberta a questão acerca do que as coisas são; mantém-se a estranheza na relação do humano com o mundo, e um desconforto invencível que contrasta com a familiaridade com que o homem não-filosófico se 
Justiça e contradição. Dissídio e reconciliação(?) na interpretação do sofista Antifonte no século XX

encontra no mundo. Esta estranheza e este desconforto são permanentes, enquanto o humano se mantém na atitude filosófica. (COELHO, 2011)

No horizonte da ética, a zetesis característica da atitude filosófica dirige-se aos fundamentos da vida comum, pondo em questão todas as bases tradicionalmente estabelecidas ${ }^{1}$.

A partir desta compreensão da Filosofia como atitude filosófica marcada pela crítica contundente e infinita de todo saber, assumindo-se a verdade como "tarefa infinita”, e assim da problematização permanente das compreensões do humano acerca de si, da cidade e do mundo, compreende-se melhor o significado filosófico da Sofística, que passa a representar-se, desta forma, como legítima representante da nova cultura filosófica.

As notícias sobre as vidas e obras dos sofistas mostram-nos empenhados em permanentes polêmicas ${ }^{2}$, o que se reflete no modo como foram transmitidos pela tradição filosófica, igualmente envolvida pela disputa - devemos a Platão, um adversário declarado, o essencial do que sabemos sobre eles.

Entre estes intelectuais, Protágoras foi o mais proeminente. A ele atribuemse três ideias centrais para compreender o séc. V a.C.: o homem-medida ${ }^{3}$, as antilogias ${ }^{4}$ e a sabedoria como o poder de tornar o argumento mais fraco, mais forte ${ }^{5}$.

A doutrina do homem-medida ${ }^{6}$ sintetiza a percepção da falta de fundamento do saber, surgido com a crise do mito como solo da autocompreensão humana. Na cultura filosófica, o homem e o seu esforço inquiridor passam a ser o fundamento do que se sabe, e não uma estória recebida do passado.

O homem, no entanto, é medida problemática - para uns o vento é frio, para outros é quente. A crise de fundamento é aprofundada com a afirmação de que é possível fazer duas afirmações opostas sobre qualquer coisa (Antilógica), o que mostra que tudo está em permanente discussão, não havendo uma verdade capaz de subtrair-se à contradição, à problematização, ao dissídio ${ }^{7}$.

Com isto, o homem sábio deixa de ser o sabedor da tradição, para tornar-se o participante perspicaz das disputas antilógicas em que todo saber está agora envolvido. Sábio é quem é capaz de defender um argumento a princípio mais fraco, levando-o à vitória.

Demonstrando sua sabedoria (seu poder de falar), os sofistas dedicavam-se ao antilegein. Em suas disputas, a sustentação das mais esdrúxulas teses, mas 
acompanhadas de argumentos capazes de torná-las convincentes, era decerto motivo de grande admiração. Que incrível, por exemplo, que Górgias sustente a inocência de Helena $^{8}$, e que encantador que seja convincente...

O prestígio intelectual passa a ser apurado no poder de argumentar e de contra-argumentar, a que a generalidade dos pensadores do séc. V se dedica. Uma parte importante da formação intelectual nesse tempo consistia em aprender a contraargumentar. Entre as provas disto estão os Dissoì $\operatorname{Lógoi}^{9}$, de autoria desconhecida, e as Tetralogias de Antifonte, textos especificamente voltados para o exercício da capacidade antilógica.

A vida intelectual no século $\mathrm{V}$ ateniense é marcada pela disputa antilógica ${ }^{10}$. Criticam-se e releem-se a história e os fundamentos éticos da cidade e da vida humana não apenas no púlpito dos sofistas, mas também no palco do teatro, igualmente marcado pelo pensamento em contraditório ${ }^{11}$.

\section{A ANTILÓGICA COMO GÊNERO LITERÁRIO}

A igualdade para falar, num quadro de acirrada disputa antilógica, abre campo para a afirmação de novos estilos e ideias. O século $\mathrm{V}$ é um século de intensa experimentação intelectual ${ }^{12}$, e por isto palco de pesquisas absolutamente inéditas. Todos os fundamentos da vida em sociedade são atingidos por perguntas do tipo: a lei deve ser obedecida? A sociedade existe por natureza ou é fruto de um acordo? Por que os homens acreditam em deuses?

A língua grega se reinventa sob a pressão dos novos experimentos do pensamento $^{13}$. Novas formas de pensar dependem de novas formas de expressão ${ }^{14}$. Todos os esforços do pensamento são esforços por inovar na língua. Ao mesmo tempo em que a disseminação da escrita permite o surgimento de novos pensamentos, estes por sua vez impõem à língua novas exigências. Forjam-se palavras e estilos de exposição e pesquisa para dar conta de novas perguntas ${ }^{15}$.

Pensamento e linguagem tornam-se objeto de amplas discussões. Surgem perguntas do tipo: o que é a linguagem? Qual a relação entre mundo, pensamento e fala? É possível dizer algo sobre o mundo? É possível pronunciar um discurso falso? Qual a origem das palavras?

Neste contexto surge a Antilógica ${ }^{16}$ como gênero ou estilo literário, como experimento intelectual e linguístico a serviço da exploração de novas formas de ideias nos diferentes horizontes do saber. 
Justiça e contradição. Dissídio e reconciliação(?) na interpretação do sofista Antifonte no século XX

Antifonte, de acordo com a leitura que fazemos, é seu representante por excelência.

\section{O FRAGMENTO 44 DE ACERCA DA VERDADE, DE ANTIFONTE: A PROBLEMATIZAÇÃO DA JUSTIÇA}

Nossa sugestão para a hermenêutica de Antifonte é a de todos os textos atribuídos a ele podem ser lidos como da autoria de um mesmo homem, que os terá escrito a demonstrar sua capacidade de manusear argumentos difíceis, e especialmente de contra-argumentar.

Sua importância filosófica, no entanto, não se reduz por isto, pois é possível que ele tenha tentado exatamente mostrar, com suas contraposições entre logoi, a incontornável natureza antilógica do pensamento humano - o que já é um lance filosófico de grande significado.

Antes de examinar a compreensão que os especialistas tiveram acerca deste aspecto na obra de Antifonte (isto é, qual radicalidade antilógica vislumbraram em seus escritos), compartilhemos aqui a leitura do fragmento 44, do tratado Sobre a Verdade, que constitui o seu mais importante trecho sobre o tema da justiça, e no qual Antifonte, em lugar de defender uma determinada concepção de justiça, mobiliza (a nosso ver) a arte antilógica para demonstrar exatamente o caráter incontornável do dissídio em que se encontra o humano no que respeita à justiça.

Sigamos a tradução de Ribeiro (2008) (DK, B 44a, B 44b, B 44c).

Este é o Fragmento 44 a:

Justiça, com efeito, é não transgredir as prescrições das leis da cidade da qual se é cidadão. De fato, um homem utilizaria convenientemente a justiça para si mesmo, se, diante de testemunhas, exaltasse as leis, mas sozinho e sem testemunhas exaltasse as prescrições da natureza. Pois as prescrições das leis são impostas de fora, as da natureza, necessárias. E as prescrições das leis são pactuadas e não geradas naturalmente, enquanto as da natureza são geradas naturalmente e não pactuadas. Transgredindo as prescrições das leis, com efeito, se encoberto diante dos que compactuam, aparta-se de vergonha e castigo; se não se encobre, porém, não. Se alguma das coisas que nascem com a natureza é violentada para além do possível, mesmo que isso ficasse encoberto a todos os homens, em nada o mal seria menor, e, se todos vissem, em nada maior, pois não é prejudicado pela opinião, mas pela verdade. $\mathrm{O}$ exame dessas coisas é totalmente justificado pelas seguintes razões: porque muitas das coisas justas segundo a lei estão em pé de guerra com a natureza, pois são dispostas por lei aos olhos as coisas que devem ver e as que não devem; e aos ouvidos, as que eles devem ouvir e as que não devem; e à língua, as que ela deve dizer e as que não deve; e às mãos, as que elas devem fazer e as que não devem; e aos pés para onde devem ir e para onde não 
devem; e ao espírito, as coisas que deve desejar e as que não deve. Com efeito, não são para a natureza em nada mais afins nem mais próprias as coisas das quais as leis dissuadem os homens do que aquelas das quais persuadem. Por outro lado, o viver e o morrer são da natureza e, para eles, o viver é uma das coisas convenientes e o morrer uma das não-convenientes. As coisas convenientes fixadas pelas leis, por seu turno, são grilhões da natureza, as fixadas pela natureza, livres. De fato, as coisas que produzem sofrimento, por uma correta razão, não são proveitosas à natureza mais do que as agradáveis; não seriam portanto em nada mais convenientes as coisas dolorosas do que as prazerosas. Pois as coisas convenientes segundo a verdade não devem prejudicar, mas beneficiar. (...) E aqueles que, tendo padecido um dano, se defendem, mas não começam eles mesmos a agir; e aqueles que fazem o bem a seus pais, ainda que esses lhes sejam maus; e os que concedem prestar juramento a outros sem que esses tenham jurado; e do que ficou dito poderia alguém encontrar muitos outros casos de guerra contra a natureza, entre eles sofrer mais, sendo possível sofrer menos; comprazer-se menos, sendo possível comprazer-se mais; e padecer o mal, sendo possível não padecer. Se, por um lado, algum socorro da parte das leis viesse àqueles que não se submetem a tais coisas, ou algum enfraquecimento àqueles que não se submetem e se lhes opõem, não seria inútil o [DK e BDC: liame/P: obedecer] às leis. Por outro lado, parece, agora, não ser suficiente para socorrer os que se submetem a tais coisas o justo que vem da lei, o qual, primeiramente, permite ao paciente padecer e ao agente, agir. E, remetendo ao castigo, em nada é mais propício ao que padeceu do que ao que agiu, pois deve persuadir os que vão castigar de que padeceu [DK: reclama para poder ganhar a causa/BDC: obter justiça por meio da ilusão]. As mesmas coisas, porém, se deixa ao agente negar. (...)

\section{Sigamos com o Fragmento 44 (b):}

[versão DK e U:] <Os que descendem de pais ilustres>, nós os honramos e os veneramos; os que não são de uma casa nobre, nem os honramos nem os veneramos. Com isso, porém, (...) agimos como bárbaros uns em relação aos outros, enquanto por natureza todos em tudo nascemos igualmente dispostos para ser tanto bárbaros quanto gregos. É o caso de observar as coisas que por natureza são necessárias a todos os homens: a todos são acessíveis as mesmas capacidades, e nem todas essas coisas nenhum de nós é determinado nem como bárbaro nem como grego. Pois todos respeitamos o ar pela boca e pelas narinas [versão DK e U:] e comemos todos com as mãos. [versão BDC e P:] e rimos quando nos alegramos no espírito ou choramos quando sentimos dor; e pela audição acolhemos os sons; e pela luz do sol com a vista vemos; e com as mãos trabalhamos/ e com os pés caminhamos (...) [versão BDC]: segundo a medida do que agrada, cada um dos homens e eles em conjunto se reuniram e estabeleceram as leis (...)

\section{Sigamos com o Fragmento 44(c):}

(...) do justo (...) o testemunhar a verdade uns aos outros é considerado justo e em nada menos útil para as ocupações dos homens. Agora, porém, quem fizesse isso não seria justo, enquanto for justo o não ser injusto com ninguém, quando não se padeceu injustiça. Pois é necessário que aquele que testemunha, ainda que testemunhe coisas verdadeiras, de algum modo seja injusto igualmente com o outro[versão DK e U:] e, ao mesmo tempo, que ele venha a padecer injustiça depois pelas coisas que disse [versão comum:] com isso, por causa das declarações desta testemunha, é preso o acusado pelo testemunho e perde seus bens ou a própria vida, por causa de alguém com quem não é injusto. 
Justiça e contradição. Dissídio e reconciliação(?) na interpretação do sofista Antifonte no século XX

\begin{abstract}
De fato, com isso é injusto, por um lado, com o acusado pelo testemunho, porque é injusto com alguém que não é injusto consigo; por outro lado, padece ele mesmo injustiça da parte do acusado pelo testemunho, porque é odiado por ele, ainda que tenha testemunhado coisas verdadeiras. E não apenas pelo ódio, mas porque deve guardar-se, todo o tempo, daquele contra o qual testemunhou, já que subsiste nele um inimigo tal que há de falar e fazer o que puder trazer-lhe algum mal. E parece que essas injustiças não são pequenas, nem as do que padece injustiça, nem as do que é injusto. Pois não é possível que essas coisas sejam justas e também o não se injusto nem padecer injustiça. Mas é necessário que ou apenas uma dessas possibilidades seja justa ou que ambas sejam injustas. E parece também que o processar, o julgar, o arbitrar, como quer que se os leve a cabo, não são coisas justas, pois a uns beneficia e a outros prejudica. Com isso os beneficiados não padecem injustiça, ao passo que os prejudicados padecem. (...)"
\end{abstract}

\title{
5. VERDADE E JUSTIÇA NO COMENTÁRIO DE BIGNONE, UNTERSTEINER, CAIZZI, CASSIN E GAGARIN: A HERMENÊUTICA SUPERADORA DO DISSÍDIO ANTILÓGICO
}

O texto colado está no centro da reconstrução do pensamento ético-político de Antifonte, assim como de sua personalidade.

O fragmento é extremamente difícil de ler, a começar por não fazermos a menor ideia do contexto a que se integra.

Por esta razão, ele se presta às mais diversas interpretações, justificando a rotulação, por alguns, de Antifonte como representante de um hedonismo egoísta, ao passo que, para outros, Antifonte é o campeão da igualdade e precursor da ideia de direitos humanos universais, de democracia social etc.

Vamos agora examinar algumas das mais importantes leituras sobre Antifonte, demarcando a diferença da leitura que temos proposto para a obra de Antifonte (e em especial para o fragmento 44 do tratado Sobre a Verdade) face às de outros pesquisadores acerca do sentido geral do seu trabalho.

O fragmento 44 é especialmente importante, por exemplo, para a interpretação geral que Untersteiner ${ }^{17}$ apresenta do pensamento de Antifonte. Untersteiner desenvolve uma análise dos textos que revela uma condição muito singular do ser humano, em que este se encontra num horizonte de relatividade e de dissídio ${ }^{18}$. Mas este dissídio não é invencível, segundo a leitura de Untersteiner - que não vê nos textos de Antifonte uma inconclusividade incontornável. Ao contrário, Untersteiner lê na referência à natureza e à verdade (que comparecem no fragmento $44 \mathrm{em}$ contraposição à lei, ao direito positivo, à convenção) uma possibilidade de superação do horizonte do dissídio. 
Untersteiner acredita encontrar no frag. 44 um plano em que o dissídio se supera: um "domínio do absoluto" em que as antíteses, tidas como típicas do direito positivo (do horizonte do nomos), podem ser ultrapassadas ${ }^{19}$.

Para Untersteiner, a contraposição da verdade da physis às technai (artes horizonte enganoso onde habitam poesia, direito e deus) é o caminho para romper com o mundo de contrastes e alcançar o absoluto da racionalidade sem dissídio.

Untersteiner favorece a physis em detrimento no nomos. Mas é difícil entender o porquê da sua escolha, em detrimento das outras concepções de justiça expostas no fragmento 44 .

O problema é que a sua recusa do nomos (identificado pelo autor como o horizonte das técnicas) em favor da natureza (que Untersteiner atribui a Antifonte, supondo ser dele a doutrina exposta por Platão em As Leis 888), encontra-se em contraste com os fragmentos - e não pode, por isso, ser admitida como a posição de Antifonte.

Além de toda a problematização da physis no fragmento 44 (como vemos no fragmento: o natural é e não é útil, prazeroso e verdadeiro - é e não é justo), não faltam em Antifonte passagens de exaltação na educação - a qual se encontra sem dúvida no horizonte das técnicas. $\mathrm{O}$ fragmento $60 \mathrm{diz}$ que "a primeira das realizações que se dão entre os homens é a educação; pois, se o princípio de uma realização é produzido retamente, retamente - é verossímil - há de vir-a-ser o fím (...)”.

Da mesma forma, Antifonte exalta a educação (e a lei e os costumes, provavelmente referidos aqui como instituidores do princípio dirigente) no fragmento 61:

(...) nada pior para os homens que a falta de princípio dirigente, isto os homens de outrora reconheciam desde o princípio: habituavam as crianças a um tal princípio e a fazerem o que lhes fora exortado pela palavra (...).

Dificilmente se conseguem compatibilizar estas passagens, que dão valor e elevado sentido moral à convenção, com uma interpretação geral do Fragmento 44 que simplesmente afirme que o justo está para além da convenção, e com a indicação desta última como horizonte do engano.

Ao interpretar a passagem do fragmento 44b, Untersteiner insiste que há ali a afirmação de um cosmopolitismo que é resultado da superação do dissídio característico do direito positivo. A partir da ultrapassagem das fronteiras entre os 
Justiça e contradição. Dissídio e reconciliação(?) na interpretação do sofista Antifonte no século XX

povos, reconstrói-se a unidade originária do gênero humano (na harmonia da physis). Nesta igualdade universal atuaria exatamente o ideal de justiça (que está para além do dissídio, do direito positivo, da convenção) de não praticar nem sofrer injustiça, em consequência do qual se devem também, interpreta Untersteiner, abater as distinções sociais de classe e de nascimento. Para além do dissídio da lei, deixaríamos de honrar as pessoas de acordo com sua classe e de viver e agir como bárbaros em nossas relações recíprocas.

Mais uma vez, Untersteiner insiste numa instância de verdade para além do dissídio - procurada sempre para além da lei. Mas isto é tampouco compatível com o valor atribuído à lei como fruto do consenso, tal como lemos no fragmento 44e: é preciso "obedecer às leis", pois apenas assim cidades e "cidadãos tornam-se mais fortes e mais felizes (...)." Note-se que Untersteiner identifica a supressão do dissídio exatamente com o atingimento do consenso, que estaria assim para além da lei, nunca com ela se identificando.

A interpretação de Untersteiner, que afirma a physis como instância superadora do dissídio em Antifonte, dificilmente se coaduna com os textos, que mantêm a physis sob forte problematização antilógica. Apesar de insistir fortemente no caráter antilógico da obra de Antifonte, mostrando que sua estrutura interna é marcada pelo dissídio - e mostrando também a contraposição face ao pensamento de outros autores, que muitas vezes a orienta - Untersteiner escolhe um entre os logoi em contraposição, para afirmá-lo como a posição de Antifonte. Isto pode revelar muito sobre as preferências do intérprete, mas pouco ajuda a entender Antifonte, cuja argumentação mantém a questão indecisa.

Vejamos agora a posição de Ettore Bignone ${ }^{20}$, que também acentua a contradição como o traço central dos textos que atribui ao Antifonte-sofista. A contraposição é a técnica utilizada por Antifonte, segundo a sua interpretação, para preparar a defesa de seu próprio ponto de vista.

Para Bignone, a problematização da justiça conduz à identificação entre justiça e concórdia. Da leitura do fragmento 44c, ele conclui que a concepção de justiça de Antifonte consiste em não causar dano a ninguém ${ }^{21}$, sendo assim a concórdia assimilada à justiça ${ }^{22}$.

Este seu argumento ignora, no entanto, que aquilo que ele considera como o “conceito fundamental” de Antifonte sobre a justiça, é apenas um logos lançado no jogo 
antilógico, exposto à contraposição assim como todas as outras afirmações que estruturam o fragmento. Justiça como não causar dano a ninguém é uma afirmação em contraste, por exemplo, com o uso da justiça como fazer o que convém, ignorando a lei quando encoberto - e com toda a problematização que Antifonte faz do horizonte do nomos.

A busca de um princípio superior em Bignone recorre especialmente à natureza como instância em que o dissídio é vencido. Já esta afirmação de Bignone dificilmente se coaduna com a identificação que ele mesmo fizera entre justiça e concórdia, uma vez que a concórdia é do horizonte do nomos, o qual Bignone agora recusará como o ponto de vista de Antifonte sobre a justiça ${ }^{23}$.

$\mathrm{O}$ argumento trabalha a assimilação entre o justo natural e o verdadeiro ${ }^{24}$ no fragmento 44 a, mostrando Antifonte como inimigo do justo convencional ${ }^{25}$. O ateniense declararia guerra contra o absolutismo da lei, que invade a vida privada e não deixa espaço para a autodeterminação. Bignone aplica uma concepção individualista, francamente anacrônica, à interpretação de Antifonte, que recebe pouco amparo dos textos de que dispomos.

Mais uma vez, lembremos que a associação entre o justo natural e o verdadeiro, ou entre o justo natural e o conveniente, encontra-se exposta à contraposição antilógica no fragmento 44 - não havendo razão para afirmá-la como a posição de Antifonte, em detrimento dos logoi que as contraditam.

Os estudos de Bignone são importantes no processo de releitura dos sofistas $^{26}$. Mas a reabilitação que ele propõe põe a perder o essencial do texto de Antifonte - o caráter incontornavelmente antilógico do pensamento humano.

Passamos à análise de Caizzi $^{27}$ sobre a argumentação nas Tetralogias $^{28}$, que avança muito na percepção do caráter problematizador dos textos de Antifonte.

Também Caizzi propõe uma instância a salvo do dissídio antilógico, tentando encontrar, entre as diferentes contraposições que estruturam as Tetralogias, “[...] a posição teórica de Antifonte” (CAIZZI, 1969, p. 45).

Ao analisar a primeira Tetralogia, Caizzi (1969, p. 47) afirma que "a tetralogia não se limita à contraposição retórica entre os dois eikota: ela quer exprimir uma mensagem mais profunda". A discussão sobre o verossímil e o verdadeiro (eikóteron e eikós) - em que ambas as partes reivindicam para si a verdade, alegando que o discurso da outra parte é apenas verossímil - leva a intérprete a acreditar que, para Antifonte, há algo que escapa ao dissídio antilógico ${ }^{29}$. 
Justiça e contradição. Dissídio e reconciliação(?) na interpretação do sofista Antifonte no século XX

O exame da primeira tetralogia, no entanto, pode levar a uma conclusão exatamente contrária. A reivindicação da verdade, feita por ambas as partes - ao contrário de ser indício da existência de uma verdade para além do dissídio - mostra precisamente como a afirmação da verdade ou da verossimilhança de qualquer fato encontra-se inevitavelmente exposta à contraposição antilógica.

A antilogia também é vivamente exercitada para colocar em xeque o valor da prova testemunhal ${ }^{30}$. O texto revela que o fato de um escravo ter testemunhado de forma espontânea (isto é, sem ser submetido a tortura) é também igualmente utilizado pelas duas partes em confronto no processo: acusação e defesa retirando, do mesmo fato, conclusões opostas ${ }^{31}$.

A acusação afirma, no seu segundo discurso:

Não certamente dizem ser o testemunho do escravo digno de confiança. Pois em tais casos não pressiona com questionamentos e torturas o escravo, mas livres são deixados.

A defesa, em contraposição antilógica, afirma o contrário em seu segundo discurso:

E o testemunho do escravo, como seria digno de confiança? Pois, aturdido pelo perigo, não é verossímil que tenha reconhecido os assassinos, mas que, aconselhado pelos senhores, tenha se curvado às suas ordens, isso é verossímil.

Também se problematiza a verossimilhança como fundamento suficiente para condenação. Para a acusação, a verossimilhança deve bastar, uma vez que os crimes premeditados, quando cometidos por pessoas experientes e com autodomínio, não deixam vestígios: "Se os assassinos, entretanto, não deixam evidências, é por verossimilhança que devemos argumentar", diz o segundo discurso de acusação.

Já a defesa, em seu segundo discurso, afirma que verdade e verossimilhança não são o mesmo, e que, portanto, a mera verossimilhança não pode ser suficiente para condenar: "Se alguém acha que essas verossimilhanças são iguais à verdade (...)."

A problematização da verossimilhança se aprofunda, ainda, com a sua utilização por ambas as partes - pois ela é invocada em reforço a ambas as posições, como se percebe em muitas passagens, em todos os quatro discursos da primeira Tetralogia. 
No primeiro discurso de acusação, por exemplo, afirma-se contra o réu: "Refutado pelas verossimilhanças e pelas testemunhas, de nenhum modo seria justo nem conveniente que ele fosse absolvido por vós." Mas para o acusado (segundo discurso de defesa), "As verossimilhanças para mim são mais como eu demonstrei (...)."

Para além da problematização da verossimilhança, a primeira Tetralogia atinge também a verdade. Tanto a acusação como a defesa afirmam que as suas afirmações são verdadeiras.

No segundo discurso de defesa, a defesa alega: "Eu, porém, mostrarei, não por verossimilhanças, mas de fato, que não estava presente”. Já o segundo discurso de acusação reivindica a verdade para o seu lado ao dizer que: "Em todo caso, não afirmamos que sejam apenas de modo verossímil assassinos, mas de fato.”

Dificilmente se pode concluir, com Caizzi, haver, nos discursos reunidos por Antifonte em tetralogias, a defesa de uma instância de verdade que transcenda a possibilidade de problematização antilógica.

Também na visão de $\operatorname{Cassin}^{32}$, a índole problematizadora do pensamento dos sofistas é fortemente acentuada. Toda identidade apenas pode ser construída no jogo das contraposições por quais pensavam ${ }^{33}$. Neste sentido, o discurso de Antifonte é uma problematização, sem que nenhuma posição sintetizadora seja definitivamente estabelecida. Toda verdade é precária, e Cassin assimila-a à concórdia (homonoia), “[...] substituto temporal e finito do ser ou da natureza na grande tradição ontológica" (CASSIN, 1990, p. 143).

Esta sugestão de Cassin convida a repensar o livro dedicado à homonoia, que recebe uma nova luz do princípio antilógico como orientador da leitura de seus textos. Em primeiro lugar, há que perguntar se este texto também não se submete ao mesmo princípio de investigação e exposição de Antifonte. Se Sobre a Verdade é uma exploração de diferentes temas para mostrar o quão invencível é o dissídio antilógico a que se submetem, não terá Acerca do Consenso um objetivo similar? Ou será dedicado a exaltar o consenso como um fundamento da cidade, consenso este que é assim admitido como possível?

Esta é decerto uma possibilidade hermenêutica. A afirmação de que não há uma instância da verdade para além do dissídio antilógico, eis que nada se deixa subtrair à possibilidade de refutação, é condizente com uma valorização do consenso (homonoia), categoria perfeitamente ajustada a um mundo estruturado de modo retórico-argumentativo, como é o mundo antilógico descrito por Antifonte. 
Justiça e contradição. Dissídio e reconciliação(?) na interpretação do sofista Antifonte no século XX

O consenso não é um logos que encerra e supera a antilogia, mas é construído no jogo de contraposições entre logoi. Ele não é verdade, mas simplesmente o compartilhamento de um mesmo logos, o qual no entanto não deixa de ser confrontado por outros logoi. O consenso é o fruto da retórica, é o seu telos, muito diferentemente da verdade a que a ciência (ou a filosofia, para usar esta palavra no sentido platônico) visa. Toda a verdade possível seria, no horizonte insuperavelmente antilógico em que o ser humano se encontra, consenso, com seu caráter finito, problemático, provisório e contingente.

A verdade-consenso está sempre em risco, e sempre por ser construída, na medida em que o caráter antilógico do pensamento humano impõe a permanente problematização de tudo.

Mas a sugestão de Cassin, de que a concórdia seja instância para além do dissídio, também é criticável. O problema em indicar o consenso como instância de superação (mesmo que provisória) do dissídio, é que os fragmentos ligados ao tema estão em tensão - de modo a sugerir que o que é objeto de consenso não escapa à problematização antilógica. No fragmento 44e, o incentivo à homonoia não tem por fim o bem daqueles que com ele se comprometem pelo juramento, "mas para serem persuadidos a obedecer às leis". Também o fragmento 49 é repleto de afirmações antilógicas (como vimos acima), assim como o fragmento 54 pode ser lido na mesma perspectiva. De todo modo, para Cassin, não há em Antifonte uma posição sobre a justiça, a qual mantém-se em reconstrução permanente, por força do pensamento em contraditório. Se há uma saída, como sugere Cassin, esta é precária e provisória - mas mesmo esta, no entanto, pode estar sendo questionada por Antifonte ${ }^{34}$.

Gagarin também enfatiza o caráter antilógico dos textos de Antifonte, recusando sua rotulação ideológica ${ }^{35}$, e acentuando o caráter problematizador do fragmento 44 e das Tetralogias ${ }^{36}$.

Isto faz com que não veja as diferentes afirmações parciais que o fragmento traz como posições de Antifonte. Assim, por exemplo, ele interpreta a afirmação de que é conveniente seguir a lei quando testemunhado (e ignorá-la em favor dos instintos naturais quando oculto) não como um conselho de Antifonte, mas como uma das várias posições integradas no jogo antilógico. 
A partir disto, ele interpreta que a relação entre physis e nomos está sendo, ela própria, problematizada, não havendo uma relação direta entre natural e bom ou entre convencional e mau, nem vice-versa ${ }^{37}$.

Do ponto de vista de Gagarin, no entanto, a proposição de antilogias está a serviço de algo que se põe acima delas, sendo um método utilizado por Antifonte para levar o leitor a descobrir, por si mesmo, a verdade para além dos logoi em contraposição. Esta posição é construída a partir da associação entre os textos de Sobre a Verdade que atinem à justiça (44a, 44b, 44c), e os textos de teor gnosiológico.

Sua interpretação do fragmento 1 , sobre a relação entre os sentidos e a inteligência, conduz à conclusão de que o dissídio antilógico está radicado apenas na sensibilidade, dizendo respeito ao modo como o homem percebe o mundo pelos sentidos. Mas este dissídio antilógico pode ser superado pela inteligência, o que permitiria o acesso à verdade, entendida então como instância superadora da antilógica $^{38}$.

Para Gagarin, o fragmento 1 oferece a distinção entre os sentidos (a visão, opsis) e o intelecto (gnome). De fato, ali há a problematização da relação entre a linguagem (a coisa enquanto falada), a sensibilidade (a coisa enquanto percebida) e a inteligência (a coisa enquanto pensada).

A rigor, devemos admitir que não é possível concluir, a partir das poucas linhas que nos restam sobre a questão, acerca de uma doutrina de Antifonte sobre da relação entre estes três pontos. De todo modo, nada parece permitir concluir, como faz Gagarin, pela superioridade do intelecto relativamente à percepção, conclusão esta que é uma peça central do seu argumento a favor da existência de uma verdade para além do dissídio antilógico.

A ideia de que a contraposição das coisas tal como percebidas pode ser superada (e uma verdade a salvo do dissídio, encontrada, com recurso ao intelecto), traz consequências ao tema da justiça, ligando-se à leitura do fragmento $44^{39}$.

Isto o leva a concluir que a problematização do par physis-nomos está a serviço de uma unidade superior a ambas, que se mantêm a salvo do dissídio ${ }^{40}$.

Vejamos os três argumentos de Gagarin em que, a partir da concepção mais complexa de linguagem e de realidade em Antifonte, o intérprete conclui pela existência de uma verdade para além do dissídio antilógico.

Gagarin defende que a oposição entre gregos e bárbaros, tomada entre as mais sólidas convicções da cultura grega, é problematizada na constituição de uma nova R. Fac. Dir. UFG, v. 42, n. 3, p.85-113, set./dez. 2018 
Justiça e contradição. Dissídio e reconciliação(?) na interpretação do sofista Antifonte no século XX

unidade, superadora ou conciliadora. Para além dos logoi em oposição (de um lado, todos somos bárbaros, de outro, bárbaros e gregos distinguem-se), existe uma instância em que esta oposição se revolve ${ }^{41}$. A physis aparece como a instância superadora do dissídio antilógico, escapando dele e reconciliando-o.

$\mathrm{O}$ segundo argumento focaliza precisamente a oposição entre physis e nomos, que parece sucumbir na medida em que o texto dá indicações de similitudes entre eles.

O terceiro argumento de Gagarin concerne à justiça, palavra resgatada em sua ambiguidade ${ }^{42}$ e que guarda sempre uma tensão entre opostos. Para Gagarin, esta oposição pode ser superada numa concepção mais elevada de justiça ${ }^{43}$.

A propositura de antilogias, em Antifonte, estrutura a sua argumentação, mas ela está, segundo Gagarin, a serviço de uma interpretação superadora, capaz de alcançar uma verdade não exposta ao dissídio. Esta verdade a salvo da antilogia não está nos textos de Antifonte, acredita Gagarin, mas pode e deve ser alcançada pelo intérprete, se ele for capaz de superar a antilogia que está na superfície (na percepção) e for inteligente o bastante para alcançá-la pela razão ${ }^{44}$.

Gagarin está certo ao identificar, como elemento nuclear do método de Antifonte, a construção de antilogias, pelas quais problematiza os conceitos mais caros de seu tempo. Esta problematização, no entanto, não parece conduzir a uma superação. A argumentação de Antifonte, nos fragmentos em questão, não indica uma superioridade da coisa tal como pensada, sobre a coisa tal como sentida.

$\mathrm{O}$ argumento de Gagarin em favor dessa superioridade reside no fragmento $2^{45}$. Mas a conclusão de que a coisa tal como pensada é (ou pode ser) mais verdadeira que a coisa tal como percebida (mantendo-se esta última apenas no horizonte antilógico) não é autorizada pelo texto citado.

Um outro problema subsiste em sua interpretação, ainda que concordemos com o significado dado por Gagarin ao fragmento 1. Admitindo-se (como Gagarin faz) que o método de Antifonte consista em reunir logoi opostos, num exercício problematizador marcado pela contraposição de opiniões, como saber se a afirmação de que o intelecto comanda o corpo, é o ponto de vista de Antifonte? Não será, como tantas vezes temos visto, uma opinião trazida para submeter-se ao contraste, à contraposição por um outro logos? 
As passagens iniciais do tratado Sobre a Verdade dão prova da problematização de temas epistemológicos, linguísticos e eventualmente ontológicos, dizendo respeito à natureza das coisas, à possibilidade de serem conhecidas e a como são ditas. Mas estes textos não oferecem mais que a própria problematização, mantendo-se Antifonte, também aqui, na afirmação de um polemos, de um dissídio antilógico que não parece encontrar solução em seu pensamento.

Também em sua análise das Tetralogias, Gagarin acentua o caráter fortemente antilógico do texto, o qual, no entanto, ele afirma estar a serviço de uma compreensão superior ${ }^{46}$ que transcende o dissídio ${ }^{47}$.

\section{CONSIDERAÇÕES FINAIS}

As conclusões dos especialistas que discutimos neste trabalho, segundo interpretamos, não fazem inteira justiça aos textos. A introdução, no "sistema" de Antifonte, de uma instância (uma opinião, verdade ou acordo) em que se ultrapassa o dissídio do pensamento humano, põe a perder uma perspectiva muito profícua para compreender Antifonte: o indecidível do mundo humano, marcado pela divisão, pela encruzilhada, pela aporia.

Em sentido diferente, propomos uma leitura segundo a qual Antifonte, por diferentes formas, reafirma que toda compreensão, todo estar-no-mundo do ser humano, é antilógico.

Neste sentido, descabe a pretensão de procurar a concepção de justiça de Antifonte.

A perspectiva antilógica parece elucidar o fragmento 44, se concebermos que o que está ali em jogo não é a afirmação da natureza, nem da lei, como instâncias da verdade em que o humano está a salvo do dissídio - mas sim a proposição de uma série de argumentos que se endereçam a esclarecer o caráter infinito da discussão, marcante no séc. V (e desde então), sobre as relações entre physis e nomos. Ao contrário de instância para além do dissídio, aprendemos com o fragmento 44 e com os demais textos de Antifonte que a referência à natureza/verdade é um lugar-comum na argumentação de homens que não conseguem transcender o dissídio que assinala a condição humana, em infinita disputa sobre a justiça. Natureza, convenção, e a sua relação com a justiça e a verdade, neste sentido, estão sendo ali problematizadas, vindo Antifonte a extrair, das concepções vigentes acerca delas, afirmações opostas às que parecem, à primeira vista, óbvias. 
Justiça e contradição. Dissídio e reconciliação(?) na interpretação do sofista Antifonte no século XX

Os intérpretes de Antifonte que convocamos neste estudo foram unânimes em ressaltar o caráter antilógico de seus textos. No entanto, ao procurar sempre reconduzi-los a alguma espécie de síntese superadora, não estariam a perder de vista o que Antifonte pretendeu essencialmente mostrar em seus textos: que não há, para o humano, perspectiva que permita superar o dissídio em que insuperavelmente se encontra?

\section{REFERÊNCIAS}

ANCILLA TO THE PRE-SOCRATIC PHILOSOPHERS: a complete translation of the fragments in Diels, "Fragmente der Vorsokratiker". Trad. Kathleen Freeman. Oxford: Harvard University Press, 1983.

ANTIFONTE. Testemunhos, fragmentos, discursos. Trad. Luis Felipe B. Ribeiro. São Paulo: Loyola, 1998.

ANTIPHON. The fragments. Trad. Gerard J. Pendrick. Cambridge: Cambridge University Press, 2002.

ANTIPHON. Discours suivis des fragments d'Antiphon le Sophiste. Trad. Louis Gernet. Paris: Société d'Edition "Les Belles Lettres", 1965.

ANTIPHON. The speeches. Trad. Michael Gagarin. Cambridge: Cambridge University Press, 1997.

ANTIPHONTE. Tetralogie. Trad. Fernanda Decleva Caizzi. Milano: Istituto Editoriale Cisalpino, 1969.

ARISTÓTELES. Rhetoric. Transl. J. H. Freese. Cambridge and London: Harvard University Press; William Heinemann, 1926.

FRAGMENTE DER VORSOKRATIKER. Hermann Diels, Walther Kranz. Hidessheim: Weidmann, 1989.

GREEK ORATORS - I. Antiphon \& Lysis. Trad. M. Edwards, S. Isher. 3. ed. Wiltshire: Aris \& Phillips Publishers, 1993.

LAÉRTIOS, Diógenes. Vidas e doutrinas dos filósofos ilustres. Trad. Mário da Gama. Brasília: UnB, 2008.

PLATÃO. As leis. Trad. Francisco de P. Samaranch. In: PLATON. Obras completas. Madri: Aguilar, 1974, p. 1274-1516. 
Protágoras. Trad. Francisco de P. Samaranch. In: PLATON. Obras completas. Madri: Aguilar, 1974, p. 160-195.

Teeteto. Trad. Jose Antonio Miguez. In: PLATON. Obras completas. Madri: Aguilar, 1974, p. 887-941.

SOFISTAS. Testemunhos e fragmentos. Trad. Ana A. A. Souza, Maria J. V. Pinto. Lisboa: Imprensa Nacional - Casa da Moeda, 2005.

THE FIRST SOPHISTS. Trad. Robin Waterfield. Oxford: Oxford University Press, 2000.

THE GREAT SOPHISTS. Translation, introduction and notes by John Dillon and Tania Gergel. London: Penguin Books, 2003.

AGUIAR, Giovânio. Ambivalência e relativismo nos dissoì lógoi. Belo Horizonte: 2006, 130 f. (Dissertação de mestrado - Curso de Pós-Graduação em Filosofia da Faculdade de Filosofia e Ciências Humanas da Universidade Federal de Minas Gerais).

BIGNONE, Ettore. Antifonte oratore e Antifonte sofista. Urbino: Argalia, 1919.

BRETONE, Mario; TALAMANCA, Mario. Il diritto in Grecia e a Roma. 2. ed. Bari: Laterza, 1994.

CAIZZI, Fernanda Decleva. Protagoras and Antiphon: sophistic debates on justice. In: LONG, A. A. (ed.) The Cambridge companion to early Greek philosophy. 10. ed. Cambridge: Cambridge University Press, 2008, pp. 311-331.

CAPIZZI, Antônio. La confluence dês sophistes à Athènes aprés la mort de Péricles et sés conexions avec lês transformations de la societé attique. In: CASSIN, Barbara. (Ed.) Positions de la sophistique. Paris: Vrin, 1986, p. 166-177.

CASSIN, Bárbara. Ensaios sofísticos. Trad. Ana Lúcia de Oliveira, Lúcia Cláudia Leão. São Paulo: Siciliano, 1990.

O efeito sofístico. Sofística, filosofia, retórica, literatura. Trad. Ana Lúcia de Oliveira, Maria Cristina Franco Ferraz, Paulo Pinheiro. São Paulo: Ed. 34, 2005.

COELHO, Nuno M. M. S. Direito, Filosofia e a humanidade como tarefa. Curitiba: Juruá, 2011.

Pessoa, Igualdade (Isegoria) e Controvérsia. Notas sobre o sentido da ideia de Direito, (co)fundadora da experiência civilizacional ocidental. Revista da Faculdade de Direito do Sul de Minas, v. 25, p. 183-192, 2007.

- Pensamento jurídico e Antilógica em Antifonte - contribuição grega à construção da Dogmática Jurídica In: Filosofia e Teoria Geral do Direito Homenagem a Tercio Sampaio Ferraz Junior, p. 897-915, 2011. 
Justiça e contradição. Dissídio e reconciliação(?) na interpretação do sofista Antifonte no século XX

COHEN, David; GAGARIN, Michael. (Eds.). The Cambridge Companion to ancient Greek law. New York: Cambridge University Press, 2005.

DODDS, E. R. Os gregos e o irracional. Trad. Leonor Santos B. de Carvalho. Lisboa: Gradiva, 1988.

DUPRÉEL, Eugéne. Les sophistes. Protagoras, Gorgias, Prodicus, Hippias. Bruxelas: Éditions du Griffon, 1948.

GAGARIN, Michael. Antiphon the Athenian. Oratory, law, and justice in the age of the sophists. Austin: university of Texas, 2002.

The truth of Antiphon's Truth. In: PREUS, Anthony. Essays in Ancient Greek philosophy VI. Before Plato. New York: State University of New York Press.

GERNET, Louis. Droit et sociéte dans la grèce ancienne. Paris: Recueil Sirey, 1955.

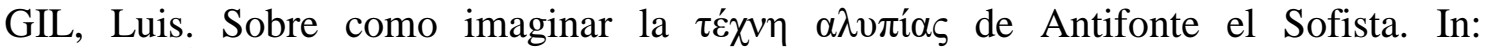
CALDERÓN, E., MORALES, A., VAVERDE, M. (Ed.) Koinòs logos. Homenaje al profesor José Garcia López. Murcia, 2006, p. 337-343.

GOODY, Jack; WATT, Ian. As consequências do letramento. Trad. Waldemar Ferreira Netto. São Paulo: Paulistana, 2006.

GUTHRIE, W. K. C. Os sofistas. Trad. João Resende Costa. São Paulo: Paulus, 1995.

HARRISON. A. R. W. The law of Athens. Volume I. London: Gerald Duckworth; Indianopolis/Cambridge: Hackett Publishing, 1984.

HAVELOCK, Eric. A. A Revolução da escrita na Grécia e suas consequências culturais. Trad. Ordep José Serra. São Paulo: UNESP, 1996. (B)

JAEGER, Werner. Paidéia. A formação do homem grego. Trad. Artur M. Parreira, 4. ed., São Paulo: Martins Fontes, 2001.

KERFERD, G. B. O movimento sofista. Trad. Margarida Oliva. São Paulo: Loyola, 2003.

LOPES, José Reinaldo de Lima Lopes. O direito na história: lições introdutórias. 3. ed. São Paulo: Atlas, 2008.

MACDOWELL, Douglas M. The law in classical Athens. New York: Cornell University Press, 1978.

MARCIC, René. Geschichte der Rechtsphilosophie. Schwerpunkte-Kontrapunkte. Freiburg: Rombach, 1971.

MARQUES, Marcelo Pimenta. A significação dialética das aporias no Eutidemo de Platão. Revista Latinoamericana de Filosofia, v. XXIX, n.1, p. 5-32, outono 2003. 
O sofista: uma invenção platônica? Kriterion, v. 102, 2000, p. 66-88.

. Platão. Pensador da diferença. Belo Horizonte: Editora da UFMG, 2006.

. Os sofistas: o saber em questão. In: FIGUEIREDO, Vinicius (org.) Filósofos

na sala de aula. Vol. 2. São Paulo: Berlendis\&Vertecchia, 2007.

MOMIGLIANO, Arnaldo. Sul pensiero di Antifonte il sofista. Rivista di filologia e istruzione classica, n. 8, 1930, p. 129-40.

RIBEIRO, Luís Felipe Bellintani. Prefácio. In: Antifonte. Testemunho, fragmentos, discursos. São Paulo: Loyola, 2008.

RUBIN, Leslie G. (Ed.) Justice v. law in Greek political thought. Oxford: Rowman \& Littelfield, 1997.

SILVA, Anna Christina da. A arte da contradição na primeira Tetralogia de Antifonte. Belo Horizonte: 2005, 201 f. (Dissertação de mestrado - Curso de PósGraduação em Filosofia da Faculdade de Filosofia e Ciências Humanas da Universidade Federal de Minas Gerais).

SNELL, Bruno. A cultura grega e as origens do pensamento europeu. Trad. Pérola de Carvalho. São Paulo: Perspectiva, 2001.

SOLMSEM, Friedrich. Intellectual experiments of the Greek enlightenment. Princeton University, 1975.

SOUZA, Raquel de. O Direito grego antigo. In: WOLKMER, Antonio Carlos. Fundamentos de história do direito. 2. ed. Belo Horizonte, 2004, p. 59-94.

TODD, S. C. The shape of Athenian law. Oxford: Oxford University Press, 1993.

THÜR, Gerhard. The role of witness in Anthenian law. In: GAGARIN, Michael; DCOHEN, David (Org.). The Cambrigde companion to Ancient Greek law. New York: Cambridge University Press, 2005, p. 149-150.

UNTERSTEINER, Mario. I Sofisti. Milão: Bruno Mondadori, 2008.

Sofisti,Testimonianze e Frammenti. Vol. IV, Firenze: La Nuova Italia, 1967.

VERNANT, Jean-Pierre. As origens do pensamento grego. Trad. Ísis Borges B. da Fonseca. São Paulo: Bertrand Brasil, 1989.

VERNANT, Jean-Pierre; VIDAL-NAQUET, Pierre. Mito e tragédia na Grécia antiga. Trad. Anna Lia A. de Almeida Prado et al. São Paulo: Perspectiva, 2005.

LIDDELL, Henry George; SCOTT, Robert. A Greek-English Lexicon. Oxford. Clarendon Press. 1940. Disponível em: <www.perseus.tufts.edu>. Acesso em: 14/10/2010. 
Justiça e contradição. Dissídio e reconciliação(?) na interpretação do sofista Antifonte no século XX

Artigo recebido em 04 de dezembro de 2018 e aceito em 31 de dezembro de 2018

1 Atinge-se “a essência conceitual de predicados como o bom, o belo, o justo, etc. (...) Efetivamente, nos diálogos que (...) devem ser considerados como as primeiras obras de Platão, todas as investigações de Sócrates assumem a forma de perguntas e respostas sobre conceitos universais. O que é a coragem? O que é a piedade? O que é o autodomínio? E até o próprio Xenofonte nota expressamente, embora só de passagem, que Sócrates desenvolvia incessantes investigações deste tipo, esforçando-se por chegar a uma determinação de conceitos." (JAEGER, 2001, p. 506-7).

${ }^{2}$ Não evitamos o uso do termo "sofista", advertindo, porém, que qualquer selo que pretenda representar o conjunto dos intelectuais em atividade no séc. V tenderá sempre a ocultar as suas diferenças. O que marca os sofistas é a singularidade. Eles estão em permanente disputa, ao invés de integrarem uma escola. Tal como anota G. Reale (1993, v. 1, p. 198), "não existe um sistema sofístico ou uma doutrina sofística; é impossível reduzir o pensamento dos vários sofistas a proposições comuns. Mas também não é verdade que as doutrinas dos sofistas individuais constituam unidades incomensuráveis entre si". Antes, trata-se de um conjunto de esforços provocados por "uma série de problemas idênticos" (1993, v. 1, p. 198). "They reached no consensus on the correct alternatives to traditional views, or even on the right questions to ask; rather, their main concern seems often to be simply to find questions or answers that would be new and different from those of others." (GAGARIN, 2002, p. 14). Para o experimentalismo intelectual do séc. V, vide Solmsen (1975).

${ }^{3}$ Não evitamos o uso do termo "sofista", advertindo, porém, que qualquer selo que pretenda representar o conjunto dos intelectuais em atividade no séc. V tenderá sempre a ocultar as suas diferenças. O que marca os sofistas é a singularidade. Eles estão em permanente disputa, ao invés de integrarem uma escola. Tal como anota G. Reale (1993, v. 1, p. 198), "não existe um sistema sofístico ou uma doutrina sofística; é impossível reduzir o pensamento dos vários sofistas a proposições comuns. Mas também não é verdade que as doutrinas dos sofistas individuais constituam unidades incomensuráveis entre si". Antes, trata-se de um conjunto de esforços provocados por "uma série de problemas idênticos" (1993, v. 1, p. 198). "They reached no consensus on the correct alternatives to traditional views, or even on the right questions to ask; rather, their main concern seems often to be simply to find questions or answers that would be new and different from those of others." (GAGARIN, 2002, p. 14). Para o experimentalismo intelectual do séc. V, vide Solmsen (1975).

${ }^{4}$ Diógenes Laércio (Vidas, IX, 50): “sobre cada coisa existem dois discursos, contraditórios”.

5 "Nisto consiste tornar mais forte o argumento mais fraco. Daqui, os homens se sentissem tão indignados com a declaração de Protágoras, pois é um logro e uma probabilidade não verdadeira, mas aparente, e não existe em nenhuma outra arte, a não ser na retórica e na erística." (ARISTOTELES, Retórica, II, 1402a23). Sobre a antilogia em Protágoras, vide DILLON, GERGEL (2003, p. 17-21). 
${ }^{6}$ As doutrinas de Protágoras são objeto de viva disputa doutrinária. Há quem o interprete como um relativista, e quem o interprete como um moralista que acredita na superioridade dos sábios (o homem-medida seria, nesta hipótese, o homem sábio). Provavelmente, suas expressões ambíguas foram objeto de diferentes interpretações também no seu tempo, tornando legítimo pensar nelas como indicações de um estado de permanente problematização. Para Cappelletti (1987, p. 100), "no se trata evidentemente de que la medida la constituya el hombre genérico o el sujeto transcendental o la sociedad como forma concreta y colectiva de la existencia humana, sino yo y tú, este individuo y aquel otro, cada uno de los hombres singulares". A interpretação individualista é encontrada no Teeteto de Platão - a que Cappelletti, por exemplo, se filia. A ela se contrapõe a interpretação genérica, defendida por Gomperz (1896), para quem a medida não é dada pelo homem singular, mas pela natureza humana. Vide também Dupréel (1948, p. 15).

${ }^{7}$ Sobre Protágoras e sua concepção de verdade como confronto, vide Gagarin (2001 p. 174-5): "(...) revelador é o fato de que o trabalho que Platão chama de Verdade, foi conhecido como Katabollontes (sc. Logoi) ou Argumentos Demolidores. Este título emprega uma metáfora de luta e implica um combate, um agon entre logoi. O present tense implica que a luta não está concluída, e assim que nenhum logos singular emerge necessariamente como vitorioso no final. (...) O título de Protágoras parece implicar que os logoi estão continuamente lutando uns contra os outros, e que qualquer verdade final deve incorporar esta luta. Cada logos deve no entanto corresponder a (um aspecto da) realidade, como no exemplo do vento quente e frio: porque o vento é ambos, então cada logos (o vento é quente; o vento é frio) corresponde à realidade. Ambos logoi são verdadeiros, assim como a verdade global (o vento é quente e frio), porque todos estes logoi correspondem à realidade."

8 "In defending Helen, he [Gorgias] explicitly challenges the traditional view and also provides arguments that seem quite unpersuasive, at least to many; presumably his speech is the weaker logos. By contrast, in Palamedes, he defends a person who, according to tradition, was tried and convicted despite being innocent." (GAGARIN, 2002, p. 25). Gorgias não muda os fatos para defender Helena, mas a interpretação sobre os fatos. "The latter is particularly notable, since Gorgias was probably the first to defend Helen while still accepting the traditional version of the facts, that Helen went to Troy with Paris; previous defenders of Helen, like Stesichorus, argued that Helen was blameless because she never went to Troy." (GAGARIN, 2002, p. 106).

${ }^{9}$ Trata-se de um texto do fim do séc. V que testemunha a dedicação do tempo ao exercício antilógico. "Dissoi Logoi são pronunciados na Grécia por aqueles que filosofam sobre o bem e o mal; pois dizem que uma coisa é o bem e outra é o mal; outros dizem que é a mesma coisa que, para uns, seria um bem e, para outros, um mal e, para o mesmo homem, às vezes bem, às vezes mal." Vide Aguiar (2006).

${ }^{10}$ A antilógica "consiste em opor um logos a outro logos, ou em descobrir ou chamar a atenção para a presença de uma oposição em um argumento, ou em uma coisa ou situação. A característica principal é a oposição de um logos a outro, por contrariedade ou contradição. (...) constitui uma técnica específica e bem definida, a saber, a partir de um dado logos, digamos, a posição adotada pelo oponente, e passar a adotar um logos contrário, ou contraditório, de maneira tal que o proponente terá de aceitar ambos os logoi, ou pelo menos abandonar a sua primeira posição." (KERFERD, 2003, p. 110).

${ }^{11}$ Para a estrutura agonística do teatro, vide Silva (2005, p. 11-74).

12 "The second half of the fifth century was a period of intellectual innovation and excitement throughout the Greek world, nowhere more so than in Athens. Poets, philosophers, medical writers and practitioners, religious reformers, historians, and others introduced new ways of thinking. They discussed and debated ideas, experimented with new methods of communication 
Justiça e contradição. Dissídio e reconciliação(?) na interpretação do sofista Antifonte no século XX

orally, often in public forums, and explored the possibilities offered by the relatively new medium of communication, writing". (GAGARIN, 2002, p. 1)

${ }^{13} \mathrm{O}$ surgimento da cultura filosófica está ligado à transformação da experiência linguística de modo essencial. O letramento tem lugar entre os gregos de modo pioneiro - processo pelo qual a leitura e a escrita difundem-se entre largas camadas da população, ultrapassando as barreiras de uma casta de funcionários que ao mesmo tempo reúne funções administrativas e religiosas e mantém o ler e o escrever como funções religiosas quase exclusivas. Ao letramento está ligada a crise da fundamentação narrativa, fundada na oralidade, característica da cultura mito-poética. Vide Coelho (2013), Havelock (1996A, 1996 B), Goody (1987) e Goody-Watt (2006).

${ }^{14}$ A disseminação da escrita possibilita novas formas de pensar também na medida em que possibilita a expressão de conceitos abstratos: "Em culturas orais, palavras - especialmente palavras como 'Deus', 'Justiça', 'Alma', 'Bom' - dificilmente podem ser concebidas como entidades separadas, divorciadas do resto da oração e de seu contexto social. Mas, uma vez dada a realidade física de escrita, elas tomam uma vida própria e muito do pensamento grego estava ocupado com a tentativa de explicar os seus significados satisfatoriamente e de os relacionar a algum princípio último de ordem racional no mundo, para o logos.(...) O procedimento lógico parece ser essencialmente letrado." (GOODY-WATT, 2006, p. 53).

15 "O nascimento da ciência da natureza, contemporâneo ao aparecimento da matemática e da lógica como ciências das formas, dá origem, portanto, a uma profunda revolução epistemológico-linguística na cultura humana que foi a formação de nomes e conceitos gerais ou universais que a língua grega, conforme mostrou B. Snell, tornou possível pelo uso do artigo definido. Sem eles não teria sido possível a ciência que é, primeiramente, ciência do universal." (VAZ, 1999, p. 57-8 - grifos no original).

16 "The writing down of oral performances led to a new form of sophistic discourse, Antilogiae, or opposing arguments. Protagoras reportedly was the first to say that 'on every subject (pragma) there are two logoi opposed to one another' (6a DK, $24 \mathrm{GW}$ ), and though nothing survives of his own Antilogiae, we may infer that it contained pairs of opposed arguments on various topics. Others followed Protagoras' lead, and several works containing arguments on both sides to survive, most notably Antiphon's three Tetralogies, each of with (following the form of Athenian homicide procedure) contains two alternating speeches by the plaintiff and the defendant. A lesser work, the Dissoi Logoi ('Double Arguments'), presents a series of theses (e.g., 'Good and bad are the same thing'), each followed by arguments in support of and opposed to the thesis. Xenophon (Memorabilia 2.1.21'24) presents a version of a work of Prodicus in which two women, Virtue and Vice, give opposed speeches, each seeking to attract Heracles to her way of life. And many speeches in Thucydides are either directly paired, as in the Mytilenean debate, or indirectly paired to respond to one another, as in the characterizations of Athens by the Corinthians in 1.17 and by Pericles in 2.36-46." (GAGARIN, 2002, p. 22).

${ }^{17}$ Mario Untersteiner (Rovereto 1899 - Milano 1981) foi professor da Universidade de Gênova e de Milão. O site do Liceu Berchet, onde ensinou grego e latim de 1926 a 1945 (https://www.liceoberchet.gov.it/storia/untersteiner.htm), é uma fonte rica de informações sobre sua vida e obra. Ele jamais emprestou adesão ao regime fascista.

${ }^{18}$ A palavra 'dissídio', empregada neste para significar a contraposição indecidível entre logoi, nós a buscamos ao texto de Untersteiner.

${ }^{19}$ Segundo Untersteiner (2008, p. 376), "seu respeito diante do dúplice mistério da natureza, como vida e como morte, deveria levá-lo a um mais alto conceito do justo. Se ele refutava a 
ambivalência do logos e qualquer irracional decisão por um dos termos da antítese, era necessário que os contrários não se elidissem, mas se conciliassem na harmonia da natureza: assim as technai tornam-se experiências universais."

20 Ettore Bignone (Pinerolo, 1879 - Firenze, 1953) foi professor de literatura grega na Universidade de Palermo (1922-1953). Em 1938 recebeu o Prêmio Mussolini, e em 1939 foi premiado como "Accademico d'Italia" daquele ano.

21 "Dunque Antifonte, come del resto avevamo visto risultare dai testi precedenti, ricerca un principio di giustizia che non rechi danno a nessuno, perché il suo criterio del giusto vuole corrispondere all'utile, e che non procuca, come dice anche qui, odii ed inimizie." (BIGNONE, 1916, p. 95).

22 “(...) è certo che alla teoria di Antifonte importava giungere alla conclusione che un perfetto concetto di giustizia, il quale secondo lui includeva necessariamente concordia e amore, doveva escludere il danno reciproco, il quale non era escluso invece dalle altre definizioni del giusto da lui refiutate e tanto meno dalle pratiche giudiziarie (...)”. (BIGNONE, 1916, p. 104).

23 A concórdia, que funda a amizade e constrói-se pela educação, quando muito pode considerar-se uma "segunda natureza" (BIGNONE, 1916, p. 105) - mas já não estamos aqui no campo do nomos?

24 "Questo era il criterio di verità che informava anche la critica di Antifonte e delle correnti di pensiero a lui affini, contro la legge scrita, in favore della legge naturale. (...) Si vede così in che rapporto strettissimo stesse com la verità, la teoria di Antifonte sulla giustizia e la sua critica della legge e degli usi giuridici, come pure il valore e la sua critica dato alla natura." (BIGNONE, 1916, p. 112-113).

${ }^{25}$ A recusa da lei como o ponto de vista de Antifonte vai ao ponto de afirmar que há em Antifonte "una specie di ribellione romantica, quale apparirà per esempio nella vivacissima protesta del Jacobi (nel suo Woldemar) contro il costume e la legge, in favore della coscienza individuale". (BIGNONE, 1916, p. 115).

${ }^{26} \mathrm{O}$ exame do fragmento 44b, em que se afirma a igualdade natural entre gregos e bárbaros, trazido em reforço à afirmação da physis como instância superadora do conflito, e indicada como a posição de Antifonte sobre a justiça, permite a Bignone "reabilitar" o sofista. Ele não é afinal um destruidor, mas o defensor de "uma moral quietista e sentimental (como de resto se poderia argumentar sobre a alypía que ele praticava)." (BIGNONE, 1916, p. 125).

\section{${ }^{27}$ Fernanda Decleva Caizzi foi Professora da Universitá Statate di Milano.}

28 "Uma tetralogia é uma sequência de quatro discursos, acusação, defesa, segundo requisitório, levando em conta a defesa, segunda defesa levando em conta o primeiro e o segundo requisitórios: essa sequência, como um jogador com a mão quente, faz com que não haja fatos, mas apenas pontos de vista recobrindo os fatos, apenas construções, interpretações, argumentos provocadores ou construtores de fatos." (CASSIN, 2005, p. 311).

29 "Nella prima serie di discorsi, lo si è visto, emerge una polemica contro la retorica fondata su eikós posta in risalto dal contrasto fra ciò che è necessario, ciò che è, e il verossimile. Il contrasto fra le funzioni tês phýseos $(\Gamma \delta 2)$ ed eikós mostra che questi è dóxa, e perciò non hà valore. La conseguenza implicita è che il diritto può risolversi in un sopruso; e questa problematica, come s'è visto, non è neppure assente dai discorsi reali." (CAIZZI, 1969, p. 69)

${ }^{30}$ Este também é um tema problematizado no fragmento 44. 
Justiça e contradição. Dissídio e reconciliação(?) na interpretação do sofista Antifonte no século XX

31 "The challenge (proklesis) issued before witnesses also is important for the rhetorical argument about the two remaining nonartistic proofs, slave testimony under torture (basanos) and oath (horkos). Bot of theses could be described as evidence in today's sense, but Athens was peculiar in that these types of evidence took place outside of court, not before the jurors. These procedures, interrogation under torture and oath, became relevant to the trial only if both parties agreed. Because slaves were not normally allowed as witnesses, a litigant could agree that one would accept an oath sworn by the other on a particular subject. In such challenges it is often suggested that the decision for the entire case should depend on the outcome of these procedures taking place outside of court. But in most cases it remains merely the suggestion of one party, because the opponent does not, as a rule, accept the challenge." (THÜR, 2005, p. 149-150).

${ }^{32}$ Bárbara Cassin é Directrice de recherche émérite do Centre Léon Robin (Centre de recherches sur la pensée antique, CNRS, Paris-Sorbonne).

33 "A identidade não é mais então o princípio de igualdade a si mesmo, de unidade e de unicidade intemporal colocado pelo eleatismo ('o ser é, o não-ser não é', e 'o que é, é um') e pela física jônica ('tudo é água' diz Tales, 'tudo é um'); ela deve, ao contrário, ser conquistada sem cessar, ser construída em toda precariedade por meio dos discursos." (CASSIN, 1990, p. 143).

${ }^{34} \mathrm{O}$ problema do consenso é extremamente desafiador no pensamento de Antifonte. A leitura de Cassin não invalida a perspectiva geral proposta aqui, do dissídio como condição invencível do ser humano, eis que ela acentua o caráter provisório de toda concórdia. É possível compreender a parte do fragmento $44 \mathrm{e}$ que nos vem por Jamblico como a prova de que o dissídio marca ineludivelmente o ser humano - este caráter antilógico é que institui o consenso como um desafio: "(...) O consenso, como o próprio nome quer demonstrar, compreende em si convergência, comunidade e unificação do mesmo senso; a partir daí, estende-se a cidades, casas comuns, todas as coletividades, bem como as casas particulares, e perpassa todas as naturezas e consanguinidades, tanto as comuns como as particulares; e também compreende o acordo de cada um em relação a si mesmo quanto ao pensamento; pois aquele que é conduzido por um só senso e um só pensamento compartilha do mesmo senso consigo; divergindo de si quanto ao pensamento, porém, entrega-se a raciocínios desiguais e por isso cai na dissensão interna; e, por um lado, aquele que persevera sempre no mesmo pensamento (durante o transitar do senso) é pleno de concórdia; por outro lado, o errante, que com cambiantes raciocínios é arrastado <sempre> por opinião diferente, é instável e inimigo de si mesmo." Mas nada indica que, para Antifonte, este dissídio seja superável, no entanto.

35 "Most discussion of $44 \mathrm{C}$ has aimed at deciding which of these rules, if either, represents Antiphon's own view, but this is perhaps the wrong question." (GAGARIN, 2002, p. 75). “(...) it may be more likely that Truth did not provide a more positive theory of justice, but rather left the reader with the aporia with which the surviving text ends." (GAGARIN, 2002, p. 78).

36 'Here [44B], too, although he criticizes some aspects of justice, Antiphon's overall view, to the extent that it can be determined, is more ambivalent, and his discussion seems directed more at analyzing the implications of popular views of justice than at condemning justice per se or establishing his own positive doctrine" (GAGARIN, 2002, p. 73).

${ }^{37}$ Para Gagarin, no fragmento 44, "Antiphon is exploring inconsistencies and contradictions within the realm of nomos" (GAGARIN, 2002, p. 78). Da mesma forma, também a physis é problematizada: "Thus the two values, pleasure and advantage, seem to be independent of each other and of nomos and physis." (GAGARIN, 2002, p. 79) "In sum, advantage and pleasure and 
their opposites are throughout seen as attributes or consequences of nomos or, less often (in the surviving text, at least), of physis. There is no hint that either might function as an objective value. Antiphon's interest is primarily in nomos, physis, and justice, and only secondarily in these attributes". (GAGARIN, 2002, p. 80).

38 "Finally, it is tempting to speculate that Antiphon's views on this subject, like his title Truth, were influenced by Protagoras's view that when one person perceives a wind as hot and another as cold, both perceptions are valid (Plato Thaetetus 152b-c). Although most people are content with their perceptions, the intellect can lead beyond these perceptions to an understanding of the truth". (GAGARIN, 2002, p. 83-4). Ele crê: "Fragment I implies that there is a kind of knowledge that is attained through the intellect, rather than through perception". (GAGARIN, 2002, p. 82).

39 "The structure of opposing logoi representing different perspectives on an act or event is also incorporated, though in a rather different form, into Truth. Here Antiphon introduces the two perspectives with a single voice, proposing, for instance, both that justice is conformity to the law and that justice is not wronging anyone who has not wronged you. These views are not resolved in Truth (at least not in the texts that survive) any more than in the Tetralogies, and thus here, too, the reader is left with the sense that the opposed views both have some validity. On the other hand, Antiphon also seems to be urging the reader, as the defendant in Tetralogy 2 urges the jurors, to recognize that each perspective has its limitations, and that an impartial consideration may be able to determine a more comprehensive truth based on everything that has been said (3.4.I-2). Thus an intelligent reader can reach an understanding beyond the opposed logoi of the Tetralogies and beyond the two perspectives juxtaposed in Truth. The possibility of greater understanding is also urged in several fragments of Concord, which suggest that the limitations of traditional human perceptions and judgments can be overcome by the application of intellect, a view perhaps grounded in a theory of perception set forth at the beginning of Truth. Concord may be directed at a more popular audience, for it tends to state, or at least imply, the truer or better view, whereas Truth and the Tetralogies force readers to think through the consequences for themselves; but there is an essential consistency in the views all these works convey." (GAGARIN, 2002, p. 173).

${ }^{40}$ The overall structure of all these remarks, then, suggests that Antiphon would have accepted on some level the linking of nomos, logos, and eikos as opposed to physis and ergon, though from a larger perspective this polarity would break down, revealing an overall unity in them that is ultimately Truth." (GAGARIN, 2002, p. 178).

41 "Antiphon observes that at some level of reality, which is our physiological composition, no one is Greek or Barbarian, for we are the same in physis." (GAGARIN, 2002, p. 86).

42 “(...) like Hesiod's eris, [justice] is a single word designating (at least) two realidades, the justice of a legal system and the justice of traditional retaliation (...)" (GAGARIN, 2002, p. 87).

${ }^{43}$ (...) "we cannot tell how far Antiphon took this analysis, but it appears at the end as if he may be appealing to a third, more general standard of justice than either of the two he has been discussing. This third standard of justice makes each of the other two kinds of justice injust. Thus we may have here the first step of an analysis that, as in the two preceding cases, begins with as opposition (between two senses of justice), proceeds to make each of the members ambivalent (each is both just and unjust), and then indicates how a larger justice might encompass them both." (GAGARIN, 2002, p. 87).

44 "He accepts the validity of perceptions and of traditional views but shows how they can lead to conflicting conclusions on specific issues. To resolve such conflicts and understand the complexity of things, one must rely on the intellect (gnome), although most people put more 

no século XX

trust in their perceptions. Antiphon's method is to direct the reader's attentions to the conflicting views that result from perception, and then try to reveal the basic silimilarities that are present together with these differences but are not so apparent. Greek and barbarian, nomos and physis, legal justice and traditional retaliatory justice all conflict in some respects, but in other respects the terms in each pair also share certain similarities. A better appreciation of this complexity can only be gained through logos - speech and reasoning - which is thus complex and may have remained ambiguous even at the end. But he holds out the hope that gnome, human intelligence, using logos, can achieve understanding, not by reflecting popular perceptions and conceptions, but by building on them to create a better, more complex truth." (GAGARIN, 2002, p. 88).

45 “(...) in all people the intellect (gnome) leads the body to health and disease and all other things'. That the intellect leads the body implies that it has a more important role in the body's physical operation than the senses do." (GAGARIN, 2002, p. 82).

46 "Each also considers his logos true in the essence of corresponding to the pragmata in question. But the overall truth (in some larger sense) of these pragmata can only be determined by the impartial jurors, who must judge not directly from the facts themselves (which are not in dispute) but from the opposed logoi of the litigants, each of which presents a different account on interpretation of these facts. Thus, one can only understand pragmata by means of logoi; any given pragmata can give rise to different logoi, each of which may truly correspond to these pragmata; and there exists an overall, impartial truth that can be discerned from the individual, self-interested logoi of the litigants. In essence, this is the principle underlying the discourse of Antilogiae: the opposed logoi each present one perspective on an issue, and from these the reader reaches an overall understanding (logos) that comprehends and supersedes the two individual logoi." (GAGARIN, 2002, p. 125).

47 "Mas é preciso que vós conheçais que nós, os adversários, achamos que com um bom senso determinamos a questão em causa, e cada um de sua parte acha que fala coisas provavelmente justas. A vós convém olhar os fatos piedosamente, pois é a partir das coisas ditas que a verdade deve ser perscrutada". (Segundo discurso de defesa, Tetralogia II). Comenta Gagarin (2001, p. 177-8): "Em outras palavras, os juízes devem decidir a verdade do caso apenas a partir dos dois logoi, e tendo em vista que cada logos corresponde às mesmas pragmata, os juízes terão de determinar esta verdade pela coerência relativa dos dois logoi. Não há nenhuma outra base para sua decisão. Por outro lado, um veredito é apenas necessário num caso real, e embora nós leitores sejamos tentados a decidir o caso, de fato nenhuma verdade final é estabelecida. No fim, a verdade da segunda tetralogia reside não no logos de qualquer dos litigantes, nem em uma escolha entre eles, mas antes na tensão dialética entre os dois argumentos." 